\title{
Formation and disintegration of the multinational states in Central Europe
}

\author{
Szeged, Hungary, 7 March 2014
}

Since the foundation of the Institute of Research on Central Europe (VIKEK) in 2006 it has helped to form the continuously growing community committed to foster scientific research on Central and Easter European (CEE) issues. Since then it has got more than one hundred members most of them are professors representing the whole spectrum of the Hungarian higher education and research centres. The institution is based in Szeged, Hungary. Its aim is to build professional network, to promote cooperation between historians, geographers, regionalists and economists dealing with the CEE region. In addition to this, the mission of the institute is to organise conferences, seminars, develop online resources and support publications related to the Central and Eastern European region. VIKEK convenes an Advisory Board in order to provide intellectual background for its activities.

The Institute for Research on Central Europe launched its conference series titled "Formation and disintegration of the multinational states in Central Europe" in 2009. Since then it has been a tradition to organise a conference every March. All the conferences focused on special focal themes of the region. So far the following conferences have been organized: 6 March 2009 - Establishment and disintegration of the Austro-Hungarian Empire

5 March 2010 - Rise and fall of the Czechoslovak states

4 March 2011 - Formation and disintegration of the Yugoslavian states

2 March 2012 - History of the Romanian states

1 March 2013 - The Ottoman Empire and the Balkans

7 March 2014 - Central Europe in the First World War and its impact on the world till now As part of the initiatives of the Institute for Research on Central Europe the conferences were aiming to contribute to the regional dialogue and cooperation through knowledge dissemination and information-exchange. The importance of such dialogues is to open new ways of cooperation in the field of scientific research through learning about different ideas, visions, approaches and methods.

The sixth annual conference "Central Europe in the First World War and its impact on the world till now" was planned to coincide with and commemorate the $100^{\text {th }}$ anniversary of the break out the war and it allowed us to reckon the Great War and its aftermath, and to explore the ways in which we have remembered it. 
The conference turned out to be a great success as with some 40 participants and their lectures from dozens of Hungarian Universities as well as Research Centres. It has provided a valuable venue for the exchange of ideas between researchers dealing with this issue. It was also a delight to watch the $\mathrm{PhD}$ students and youth participants take an active role in the conference.

The conference programme included plenary session with six keynotes and parallel sessions. The keynote speakers of the event summarized the core message of the conference, the most important political, regional, economic and social consequences of the Great War.

The first plenary speaker László Gulyás pointed to the consequences of the war as that of new countries emerged after the war however their state-building efforts often crossed each other, generating new conflicts in the region. István Szilágyi spoke from the point of view of the geopolitical legacy of the Versailles System. He introduced that from the collapse of the Russian, Austria-Hungarian and Ottoman Empires emerged Poland, Lithuania, Finland, Yugoslavia, Estonia, Czechoslovakia, Lithuania and Hungary. All this had such an impact on the map of Central and Eastern Europe as it had not been seen since 1815. Ferenc Szávai presented the economic dimension of the peace treaty and the Versailles System. His lecture focused on the reparations imposed upon the Central Powers as Germany and its allies responsible for all 'loss and damage' suffered by the Allies during the war.

Zoltán Hajdú was to discuss the enormous changes in the Balkan region after 1918 and the modernization attempts of the South-East European countries between the two world wars. The whole region was even in these times in the vital interest and crossfire of great powers. The presentation of Béla Baranyi was about the border issues after the Peace Treaty of Trianon, and the vision of the rethinking of borders was introduced. Gyula Horváth focused on the regional science in the Carpathian Basin and presented a book-series titled 'Regions of the Carpathian Basin' issued by Centre for Economic and Regional Studies of the Hungarian Academy of Sciences, and its latest volume South Pannonia.

The last moment of the morning programme was about introducing the Central European Papers, a new academic peer-reviewed journal published by the Silesian University in Opava, Faculty of Public Policies (Czech Republic), in cooperation with Kodolányi János University in Székesfehérvár (Hungary). The journal gives publishing opportunity to researchers in the field of modern history, politics and society in Central Europe. The first two volume was reported by the two chief editors, Andrej Tóth and László T. Vizi, as well as by Edit Bencze Lőrinczné, member of the editoral board.

The afternoon work followed in four parallel sections.

The first section, moderated by Béla Baranyi, investigated the role of the Austro-Hungarian Monarchy in the First World War as well as its after-war consequences. Presentations were given from 12 cohort studies form the war period and the time after collapsing the Dual Monarchy.

The second section was led by Norbert Pap. It was discussed throughout nine presentations how the political geography of Southern Europe has changed during the history. These revolutionary changes came to be a laboratory within which to examine larger global issues of the region, as well as the Balkans subregions.

Eight presentations belonged to the third session moderated by Gábor Csüllög. The panel 
was to discuss the enormous changes, the positive and negative aspects of regional developments, making difference between regionalism and regionalisation in Central Europe from the Great War on till the present days.

The fourth session led by Zoltán Kaposi focused on the economic history of Central Europe form the late nineteenth century till now. The eleven presentations demonstrated the huge economic lag of the region and the region's relative economic backwardness compared to Western Europe. The lectures tried to give proper and positive answers to the question how this legacy could be overcome.

The different sessions provided a good framework for wider discussion on Central European issues. The conference has undertaken theoretical and empirical lectures in the fields of the Great War, its economic and geopolitical legacy on states, in regional processes and in other interdisciplinary areas of Central Europe. Indeed, the conference was buzzing with lively discussion and debate, not only during the interactive sessions, but also around the coffee tables!

If you are interested in the conference topic you can read all the papers, as well as all the conference presentations that are to be published in the conference proceedings in Central European Releases issued by the Institute for Research on Central Europe. The previous conference proceedings are also to be found on the web of the VIKEK: http://vikek.hu/.

\section{Edit Bencze LŐRINCZNÉ}

Institute of Social Sciences and Liberal Arts Department of International Studies and History Kodolányi János University of Applied Sciences Székesfehérvár, Hungary 